\title{
Competency Identification Of Officials In Public Service
}

\author{
${ }^{1}$ Dr. M. Hadi Shubhan, ${ }^{2}$ Dr.Eman, ${ }^{3}$ Dr. Rr Herini Siti Aisyah, \\ ${ }^{I} \mathrm{Sh}, \mathrm{Mh}, \mathrm{Cn},{ }^{2} \mathrm{Sh} . \mathrm{M} . \mathrm{S},{ }^{3} \mathrm{Sh}, \mathrm{Mh}$
}

\begin{abstract}
This study was focused on the strategic and technical needs to increase the capacity of the local government building, primarily related with the improvement of the official performance in public services in accordance with the development of the society in order to accelerate the realization of Good Governance. The competency of the officials in public service is a complicated structure of knowledge, values, morals, attitudes, behaviors, and motivations tightly attaching every civil servant in order to be able to provide professional service to the public. Some factors causing the lower competency of the state officials are (a) the poor system of the recruitment of employee candidates, (b) improper placement of employees, (c) unbalanced workload compared to the number of and the competency of the employees.
\end{abstract}

Keywords : competency, service, public

\section{Introduction}

Since 2012 there have been identified 200 cases of public service disputes and they are going to be processed in courts under the criminal law in East Java (http://suarakawan.com/2012/10/02). These disputes occured as a logical consequence of the Act No. 14 the Year 2008 on the Openess of Public Information. Article 52 states that the Public Agency is subject to imprisonment for a maximum of 1 (one) year and/or a

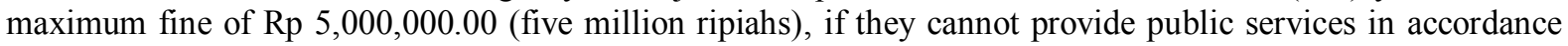
with the Act.

The increasing number of complaints related to the performance of the bureaucracy in the ministries have resulted in some improper ways of taking a shortcut to get the service (Gatot Pramuka, 2010:1). The aim of the study is to explore the issues related to the human resources in field connected to the efforts to improve the public services. The focuses were aimed to the strategic and technical needs to increase the capacity of the local government building, primarily related with the improvement of the official performance in public services in accordance with the development of the society in order to accelerate the realization of Good Governance.

\section{Literature Review}

Based on the data obtained up to December 2012 the are still a number of problems in the bureaucracy related with the human resource management, improper assignment of the civil servants, and the high proportion of structural officers who do not meet the standardadized education and training for the ranks. Besides the standardized job competency and regulations for performance appraisal are not available. The placement of the civil servants have not been proportional (http://www.polmankab.go.id/?p=2113). According to the Decree No: 63/KEP/M.PAN/7/2003, the Principles of Public Service are : (1) Transparency, (2) Accountability (3), Conditional, (4) Participatory, (5) Equal Rights, and (6) the Balance in Rights and Responsibilities. While the key principles underlying the good governance are (1) Accountability, (2) Transparency, and (3) People's Participation (Loina Lalolo Krina P , 2003: 8)

Corruption, Collusion and Nepotism practices $(\mathrm{CCN})$ are easily found and some are due to : (1) the exisiting laws and the regulations still providing opportunities for corrupt practices; (2) the difficulties to change the culture from being served to serving the people, (3) the lower level of the discipline of the people and of the officials, and (4) the poor function of the control of the government authorities including law enforcement officers . (Feisal Tamin, 2004, 2). The behavior of individuals within an organization is influenced by several things: perception, attitudes, personality and learning. ( Siswanto, 2005:76 )

Some efforts to improve the quality of the service can be done by evaluating the performance of the organization. One of the ways to evaluate the performance of the service provider is to analize the gaps between the services provided and the services highly expected by the people and they are as follows (Zaithami , 2003; 8 ) :

1. The gap between the expectations of the people and the perception of the management.

2. The gap between the perception of the management and the public service specification.

3. The gap between the public service specification and the delivery of the services.

4. The gap between the external communication to the public and the process of and the delivery of the services. 
5. The gap between the public service expected by the people and the public service perceived by the people.

There have been stated several issues related to the development of the state officials in the Act No. 17 the Year 2007 on the Long Term National Development Plan 2005-2025 and they are as follows: (a) A lot of problems in the implementation of the development the programs of the state officials in the administration of the state and the government. (b) Some problems in authority abuse practices. (c) No significant results in the earnest efforts to eradicate corruption. (d) Ineffective, both central and local, institutional governments in assisting the implementation of the tasks and the systems of the government management.

\section{Research Method}

The Socio Legal approach (Afdol, 2008:11) was applied in this qualitative research approach and it was highly expected that the review could be done comprehensively and deeply. The study was initiated by reviewing some various laws and regulations related with the competency of the officials of the government bureaucracy. The the government officials were identified in terms of the implementations of the legislation, of the principles of Good Governance and also the behavior of the authorities to find out the best solutions for public services in order to create and bring good local governance into reality. In-depth interviews were conducted to explore the information deeply and comprehensively, and then followed by the discussions to talk about the results in the technique Focus Group Discussion (Bungin , 2001:172).

\section{Competency of The Local Government Officials}

\section{Results And Discussion}

In the context of the Administration System of the Republic of Indonesia, the competency of the state officials are classified into 4 types, namely (Joko, 2003:75-76): (1) The technical Competence in the Regulation no. 101/2000 on Educataion and Job Training of the civil servants is the ability of the civil servants in a specific technical area for the implementation of each task. (2) The Managerial Competence is associated with the different managerial competencies skills required in dealing with the organizational tasks including the ability to apply the concepts and the techniques of planning, organizing, controlling and evaluating the performance of organizational units, as well as the ability to implement the principles of good governance. (3) Social Competence is communication skills required by the organization in the implementation of its core functions, and motivating the human resources or public participation in order to increase the productivity of the labor, or relating to the external environment such as implementing partnerships, collaboration and working network development with various agencies in order to improve the image and performance of the organization, including how to demonstrate the sensitivity to human rights, socio-cultural values and aspirations and responsiveness to the community dynamics. (4) Intellectual/Strategic Competence is the ability to think strategically a vision far ahead. Intellectual competencies include the ability to formulate the vision, mission, and strategy to achieve organizational objectives as an integral part of the National development, formulating and providing some logical and systematic inputs for problem solving and decision making, and also in terms of the ability to understand the relevant development paradigm in achieving good governance and the goals of the nation as well as the ability to explain the position, the duties, the functions of the agency organizations in relation with the Administration System of the Republic of Indonesia. Here are the human resources of Sidoarjo regency government statistically described.

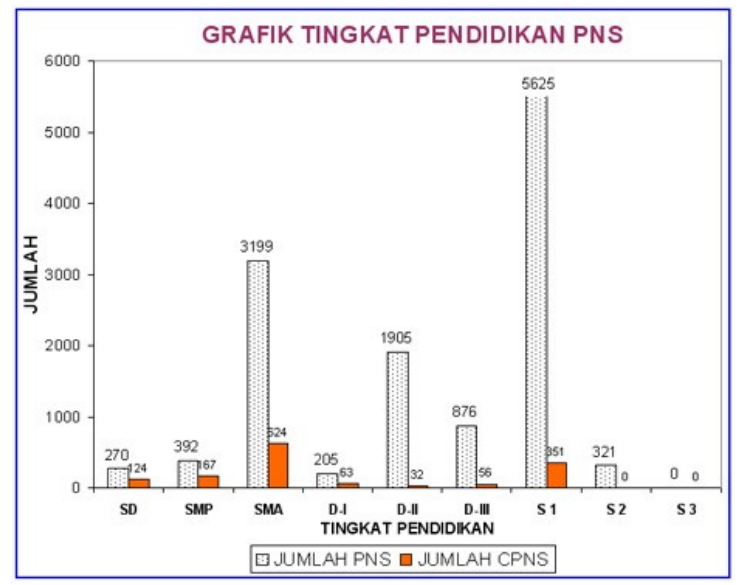

Data source : Sidoarjo Regency.

Graph of the Education Level of the State Employee 


\section{The number of State Employees}

The number of the Candidates of State Employees

Jumlah $=$ number

Tingkat Pendidikan $=$ Eductaion Level

\section{Identification of Competence of Officials in Public Service}

Act No. 43 of 1999 on the Amendment of Act 8 of 1974 on the Principles of Civil Service Article 17 paragraph 2 states that the appointment of civil servants in a position held by the principles of professionalism in accordance with the competence, performance/achievement, and the rank specified for the job as well the other objective requirements regardless of gender, ethnicity, religion, race, or class. Act no. 25 of 2009 on Public Services (Act 25/2009) in Article 1 paragraph 1 states that public service is an activity or series of activities to meet or to fulfill the service requirements on goods, services, and/or administrative services provided by public service providers/agencies in accordance with the laws or regulations for all citizens and residents. Meanwhile, according to Minister of State for Administrative Reform Number: Kep/25/M.Pan/2/2004 on the General Guidelines for the Preparation of Index on People's Satisfaction in the Service Unit of Government Agencies. Public services are all service activities undertaken by public service providers as addressing the needs of service of the recipients, as well as the implementation of the provisions of the legislation. A friendly and professional service has become a requirement conducted and fulfilled by the organizers of the work of state administration (Bob Waworuntu, 1997, 18). Characters and values in public service must contain some values of preference in society. Society is dynamic, and thus the characters of the public service must also keep abreast of ever-changing society. (H.A.S. Moenir, 2006: 70). The Competency of state officials are classified as follows: Based on the Attachment 3 of the Head of the Civil Service Regulation No. 7 of 2013 on Guidelines for Preparation of Managerial Competency Standards as illustrated in the following table .

\section{Managerial Competency Categories}

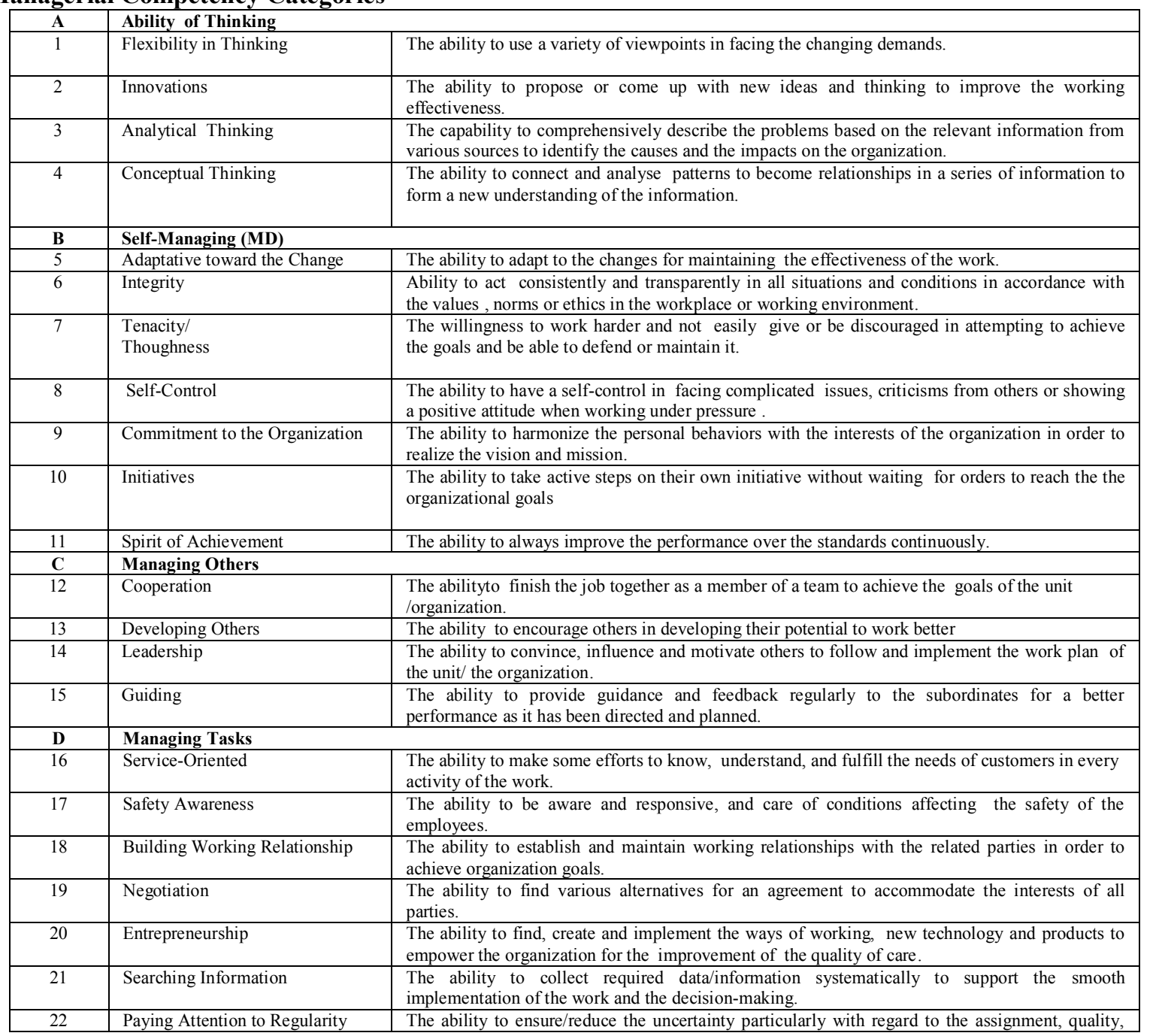




\begin{tabular}{|c|l|l|}
\hline & & and accuracy/ precision of data and information in the workplace. \\
\hline 23 & Oral Communication & $\begin{array}{l}\text { The ability to deliver opinions/idea/ information verbally using words/phrases that are easy to } \\
\text { understand. }\end{array}$ \\
\hline 24 & Written communication & $\begin{array}{l}\text { The ability to deliver opinions/idea/ information clearly using written language and grammar } \\
\text { properly. }\end{array}$ \\
\hline 25 & Decision-Making & $\begin{array}{l}\text { The ability to take quick and accurate actions and consider and be responsible with the effects of } \\
\text { the decision. }\end{array}$ \\
\hline 26 & Organizing & $\begin{array}{l}\text { The ability to coordinate the implementation of the Work to be run in accordance with a } \\
\text { predetermined plan. }\end{array}$ \\
\hline 27 & Planning & $\begin{array}{l}\text { The ability to design a specific, realistic, and measurable work plan in accordance with the } \\
\text { vision, mission and long-term goals. }\end{array}$ \\
\hline 28 & Management of Change & $\begin{array}{l}\text { The ability to manage resources to deal with the changing demands to achieve the organizational } \\
\text { goals with better performance } .\end{array}$ \\
\hline 30 & Management Conflict & $\begin{array}{l}\text { The ability to execute tasks by considering all aspects of the work in detail to achieve a better } \\
\text { quality }\end{array}$ \\
\hline $\mathbf{E}$ & Managing Social and Cultural Rights & The ability to take steps to manage the disputes towards a productive direction. \\
\hline 31 & Responsive to Cultural Influence & $\begin{array}{l}\text { The ability to appreciate the diversity in culture and its differences as the background of the } \\
\text { individual employees and the surrounding communities. }\end{array}$ \\
\hline 33 & Empathy & $\begin{array}{l}\text { The ability to listen and understand the thoughts, feelings, or other people's problems which } \\
\text { cannot be uttered or are not fully delivered. }\end{array}$ \\
\hline & Social Interaction & $\begin{array}{l}\text { The ability to build contacts or reciprocal relationship resulting in an influtial process influencing } \\
\text { individuals, among groups or between individuals and groups } .\end{array}$ \\
\hline
\end{tabular}

Causing Factors of the Lower Competency of Officials

1. Recruitment System of Civil Servants

Act No. 43 the year 1999 on the Amendment of Act No. 8 the year 1974 on the Fundamentals of Employment Article 17 (2) states that the appointment of civil servants in a position held by the principles of professionalism in accordance with the competency, performance, and levels of the rank assigned to the job as well as other objective requirements regardless of gender, ethnicity, religion, race, or class. Article 25 (1) on the Appointment, Removal and Dismissal of the civil servants carried out by the President. (2) To facilitate the implementation of the appointment, transfer and dismissal of civil servants referred to paragraph (1), the President may delegate some of the authorities to the officials/supervisors of the central employment office and delegate some of them to the local officials further regulated by Government Regulation. Although it is stated that the president can delegate some of the authorities to the regional officials, in practice the recruitment process is highly centralized. Due to the matter, complaints are often extended. Regional and local goverments only propose the number of required employees but the quotas and accepted employees depending on the central government. Consequently, it often occurs that what is considered important and urgent by the regional or local governments are not met.

\section{Employee Placement}

The principle of The Right Man On The Right Place /Job is the key to any deployment of staff in order to achieve organizational goals effectively and efficiently. Ironically, it is easily found that the placement of employees is not in line with what the regional or local governemnts expect. The principle above is frequently ignored by the government bureaucracy so that when people demand to be served well, they often fall in disappointment. Sometimes political factors play an important role. They are taken into a strong consideration in the placement of employees in strategic positions but less attention to the competency of the employee is given. The large number of central civil servants placed in Regional or Local Governments results in a negative impact on staffing policy, especially the placement of structural positions which is not in accordance with the competencies and needs.

The Decree of Government Regulation No. 13 the year 2002 on the Amendment to Government Regulation No. 100 the year 2000 on the appointment of civil servants in the Civil Structural Position states that Baperjakat of the Central and Regional Agencies and Baperjakat of Province/Regency/City have the duties to give some considerations to Trustees of Personnel Officer in the appointment, transfer and dismissal.

\section{Balance of Workload.}

Workload is determined by the work targets and the available capacity and competency of the incumbent. In the explanation of Indonesian Government Regulation No. 46 the year 2011 Article 5 Paragraph (2) b it is stated that target is the amount of workload that will be achieved in any implementation of the duties. Conceptually workload is the work to be done in accordance with the analysis of the employee position already determined. In practice, however, it is easily found that the imbalance between the workload to be accomplished and the existing resources. The shortage is mainly for personnels of education, IT, healthcare and accounting. It suggests that the competency and professional skill related with formal education are still far away to achieve because the development of such professional human resources takes a long time . 


\section{Conclusions}

1. The competency of the officials in public service is a complex structure of the knowledge, values, morals, attitudes, behaviors, motivations in every civil servant to provide professional service to the people. In the current era of the bureaucratic reform, it has been observed that a lot of officials of public service are seriously lack of strategic, managerial and technical competencies to provide professional public services demanded by the society.

2. The competency of the personnel of public service is specifically regulated in the State Employment Agency Regulation No. 7 the year 2013 on the Preparation of Managerial Competency Standards of Civil Servants and the regulation No. 8 the year 2013 on Guidelines for the Formulation of Technical Competency Standards of the Civil Servants. Referring to those regulations, it is already clear that every civil servant must be equipped with such competencies, and it can be used as a reference in the development of human resources which plays a very strategic role. If the government bureaucracy employs such qualified human resources in accordance with the expected competencies, providing professional public service is not a matter and thus they can be Agents of Change for the betterment of the nation and the State.

3. The causing factors of the low competence of the state officials are: (a) the poor recruitment system for the candidates of civil servants. (b) Improper placement of the officials and the ignorance of the principle The Right Man On The Right Place/Job. Political factors, however, are often applied as the primary considerations rather than the aspects professionalism. (c) The unbalance of workload compared to the number of employees with the expected competencies is a serious handicap.

\section{Recommendations.}

1. In the recruitment system of prospective employees, it should be noted that the involvement of a third party, like universities, in the selection process of the competent human resources is highly recommended. They design the selecting materials and the standards of the passing grade. The involvement of a third party here is to ensure the independency and competency, so that it can minimize the corruption, collusion, and nepotism resulting in selecting and recruiting the right, expected personnels with required competencies .

2. In determining the appointment of state employess for certain structural positions, the involvement of a third party, like universities, to perform fit and proper tests for the candidates, is also crucial. The involvement of such state univeristies can assist to recruit the officials with high integrity and capabilities.

3. It is required an act of a remuneration system to regulate civil service to complement the existing Civil Service Act. The act is to regulate the remuneration based on the competency. Employees with more responsibilities should be paid higher. It is for the fairness and stimulation. The employees are triggerd to work harder and achieve theri better performance.

\section{References}

[1]. No Name, Handout Penyusunan Standar Kompetensi Manajerial Direktorat Standardisasi Dan Kompetensi Jabatan Kedeputian Bidang Pengembangan Kepegawaian Badan Kepegawaian Negara 2013

[2]. Joko Triwiyatno UPAYA PENINGKATAN KOMPETENSI PNS MELALUI PERUBAHAN POLA PIKIR, Widyaiswara Madya Badan Diklat Prov. Jawa Tengah. $2003: 75-76$

[3]. Bob Waworuntu, Dasar-Dasar Keterampilan Abdi Negara Melayani Masyarakat, Gramedia Pustaka Utama, Jakarta, 1997, h. 18.

[4]. Peraturan Kepala Badan Kepegawaian Negara Nomor 8 Tahun 2013 Tentang Pedoman Perumusan Standar Kompetensi Teknis Pegawai Negeri

[5]. Afdol, 2008, Pengembangan Teori Implementasi Hukum Waris Islam Di Indoensia, Pidato Pengukuhan Guru Besar, Unair, Surabaya

[6]. Bungin Burhan, 2001, Metodologi Penelitian Sosial ,: Airlangga University Press, Surabaya

[7]. Tamin Feisal, 2004, Transformasi Budaya Kerja Aparatur Negara,

[8]. Siswanto, 2005, Pengantar Manajemen, PT Bumi Aksara, Bandung

[9]. P loina lalolo krina, 2003 indikator \& alat ukur prinsip akuntabilitas, transparansi \& partisipasi, sekretariat good public governance badan perencanaan pembangunan nasional jakarta - agustus

[10]. Undang Undang Republik Indonesia Nomor 14 Tahun 2008 Tentang Keterbukaan Informasi Publik

[11]. Pramuka Gatot, 2010, : Masalah Birokrasi Sebagai Pelayanan Publik, Jurnal Masyarakat Kebudayaan dan Politik, Vol, 20, no. 123-34, Kumpulan Artikel Ilmiah Universitas Airlangga, Nopember

[12]. Zaithami, 2003, Dalam Penyusunan Standar Pelayanan Publik, Lembaga Administrasi Negara, Jakarta

[13]. $\quad$ http://www.polmankab.go.id/?p=2113 Posted by: Dian Afrianty 19 Agustus 2013 in Berita Leave a comment) 